\title{
Experiências Poéticas: um relato de estudos teóricos e práticas artísticas do Artista/Pesquisador ${ }^{29}$
}

José Carlos da Rocha

\begin{abstract}
RESUMO: O presente artigo tem como objetivo apresentar um relato sobre os estudos e as experiências de práticas artísticas no Grupo de Estudos Estúdio de Pintura Apotheke utilizando possibilidades de técnicas de impressão que convergem para um campo expandido experimental da poética do artista/pesquisador. Nesse sentido, relatam-se principalmente duas experiências, sendo a primeira a técnica de monotipia a óleo, originada por Castiglione em 1648, tendo como referência o artista Kahn (2013) e Meyer (2006). A segunda, a técnica de cianotipia, uma reprodução artística pela fórmula de sais de ferro descoberta por Herschel em 1842. Como fio condutor, utilizo-me de minhas próprias obras, reconfigurado-as como experiências pessoais para meu aprendizado e conhecimento.
\end{abstract}

Palavras-chave: Experiência; Monotipia; Cianotipia; Artes Visuais.

ABSTRACT: This article aims to present an account of studies and experiences of artistic practices in the studio Group Apotheke, using possibilities of printing techniques that converges to an expanded field of experimental Poetics of artist/researcher. In this sense it is reported mainly two experiences, the first being the Monotype technique, oil originated by Castiglione in 1648, having as a reference the artist Kahn (2013) and Meyer (2006), and the second, the technique of cyanotype, artistic rendition by the formula of iron salts discovered by Herschel in 1842 . As a guiding principle, the author uses his own works reconfigured them as personal experiences for their learning and knowledge.

Keywords: Experience; Monotype; Cyanotype; Visual Arts.

\section{APOTHEKE - ESTÚDIO DE PINTURA \\ Práticas artísticas e teóricas de pintura}

\footnotetext{
29 Texto desenvolvido durante as aulas da disciplina Sobre Ser Professor Artista, ministradas pela Prof ${ }^{a}$. Dra . Jociele Lampert, no Programa de PósGraduação em Artes Visuais (PPGAV) da UDESC.
} 


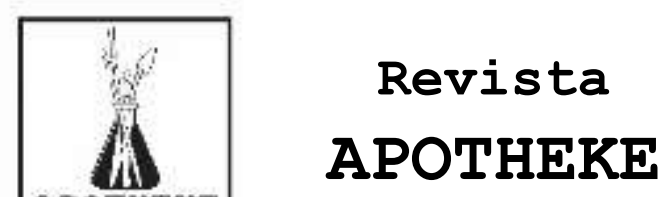

O Estúdio de Pintura Apotheke formou-se pelo desejo de um grupo de artistas/professores/acadêmicos em pesquisar, estudar e praticar juntos processos artísticos de pintura, pensando experiência e Arte Educação, em fevereiro de 2014. Desde o princípio, o grupo se reúne semanalmente para estudos de práticas artísticas e teóricas e considera o processo criativo como uma impulsão para implantar o pensamento visual individual e a Arte como a experiência, que movimenta e propicia deambulações e conexões. Seu objetivo principal é propiciar o estudo de processos pictóricos, bem como a possibilidade de ensino que envolve a pintura, não como meio tradicional, mas em um campo expandido. Dessa forma, o espaço do estúdio/ateliê torna-se ampliado para práticas que envolvem a investigação artística no ensino e processo de criação, oferecendo ações de extensão, oficinas de práticas artísticas, conversas com artistas professores, bem como exposições de trabalhos práticos desenvolvidos. Atualmente, o Grupo Apotheke está vinculado ao Departamento de Artes Visuais (DAV) e de PósGraduação em Artes Visuais (PPGAV) da UDESC, sendo formado por alunos, ex-alunos, bolsistas de iniciação científica e de extensão e por alunos do Mestrado e Doutorado. Em 2014, seu projeto foi reconhecido e aprovado como grupo de estudos e pesquisa pelo CNPq.

- Grupo de Estudos Estúdio de Pintura Apotheke é coordenado pela Professora Dr. ${ }^{a}$ Jociele Lampert e teve como membros presenciais no ano de 2014: Adão Swatowiski, Ana Camorlinga, Carolina Ramos, Daniela Almeida Moreira, Denílson Antônio, Fábio Wosniak, José Carlos da Rocha, Leandro Serpa, Luciana Finco Mendonça, Márcia Amaral de Figueredo, Marisete Colbeich, Osmar Yang, Rita Eger, Sílvia Carvalho, Talita Esquivel e Tharciana Goulart. Após sua formação, o grupo iniciou uma programação intensiva, com encontros semanais pautados em estudos das linguagens pictóricas e suas práticas. Nesse sentido, todos os integrantes têm a oportunidade de conhecer e praticar novas técnicas e executá-las por meio do processo artístico. Foram abordados vários temas ao longo dos trinta e sete encontros no ano de 2014, e desses encontros cito algumas técnicas que me fascinaram e propiciaram aumentar e aprofundar meu conhecimento e experiências.

\section{Estudo de Técnica de Monotipia a óleo}

Essa é uma técnica de impressão simples, que possibilita criar uma poética com pouco material. Permite gravar um gesto, uma emoção, uma lembrança de um objeto afetivo, de um retrato ou paisagem. O próprio nome esclarece - mono (único) e tipia (impressão) - ou seja, que 


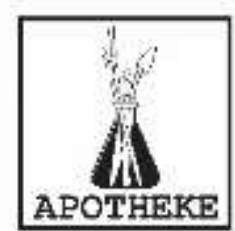

\section{Revista}

APOTHEKE

se obtém de uma prova única. Usa-se tinta a óleo, placas de vidro e papel. O artista Wolf Kahn foi nossa referência. Entretanto, o artista Edgar Degas usou essa técnica com maior frequência e produziu uma série significativa de monotipias.

Abordo minha experiência com essa técnica no item específico Relato de experiências com monotipia. A seguir, um exemplo/trabalho finalizado.

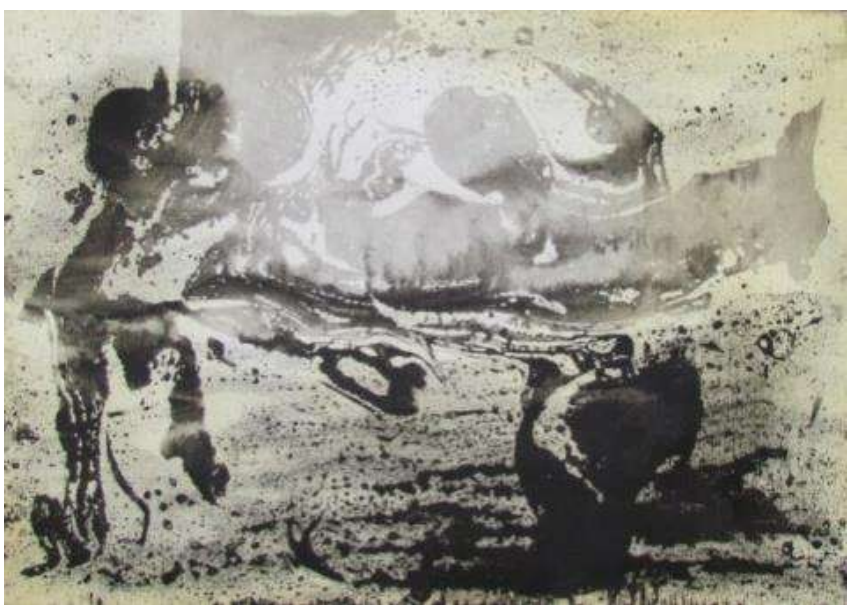

Figura 1: Metamorfose, 2014

Técnica: Monotipia a óleo

Dimensões: $20 \times 30 \mathrm{~cm}$

Fonte: Acervo do autor

\section{Estudo de Técnica de Cianotipia}

A Cianotipia é uma técnica de fotografia, mas exige um pouco mais de conhecimento e cuidado que a monotipia. Usase material que necessita de cuidados especiais, como solução química preparada, mas o resultado é compensador. Comento minhas experiências com essa técnica no item específico Relato de experiências com cianotipia. A seguir um exemplo finalizado.

Figura 2: Identidades, 2014 Técnica: Cianotipia - Foto e obra do autor Dimensões: $20 \times 30 \mathrm{~cm}$ Fonte: Acervo do autor

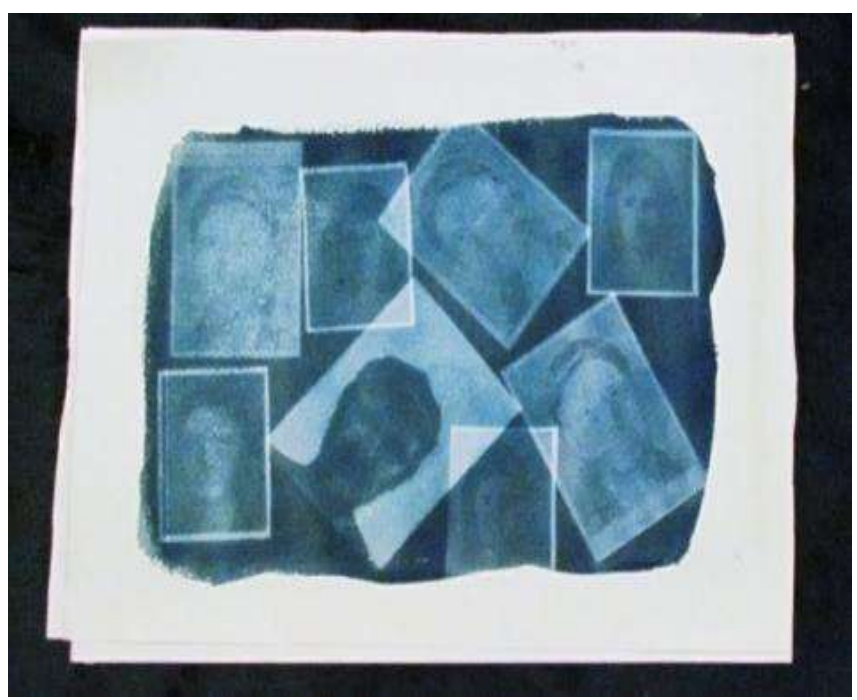




\section{Estudo de Técnica Bidimensional Encáustica}

Esta é uma técnica pictórica antiga que usa cera (idealmente de abelhas) e resinas misturadas como material para fazer trabalhos artísticos. Sua aplicação exige aquecimento anterior para ser utilizada, e a temperatura tem de ser controlada devido sua condição inicial ser sólida. A técnica de encáustica é um processo que exige bastante atenção e instrumentos adequados para se trabalhar em alta temperatura. Apresento um trabalho que foi realizado com essa técnica.

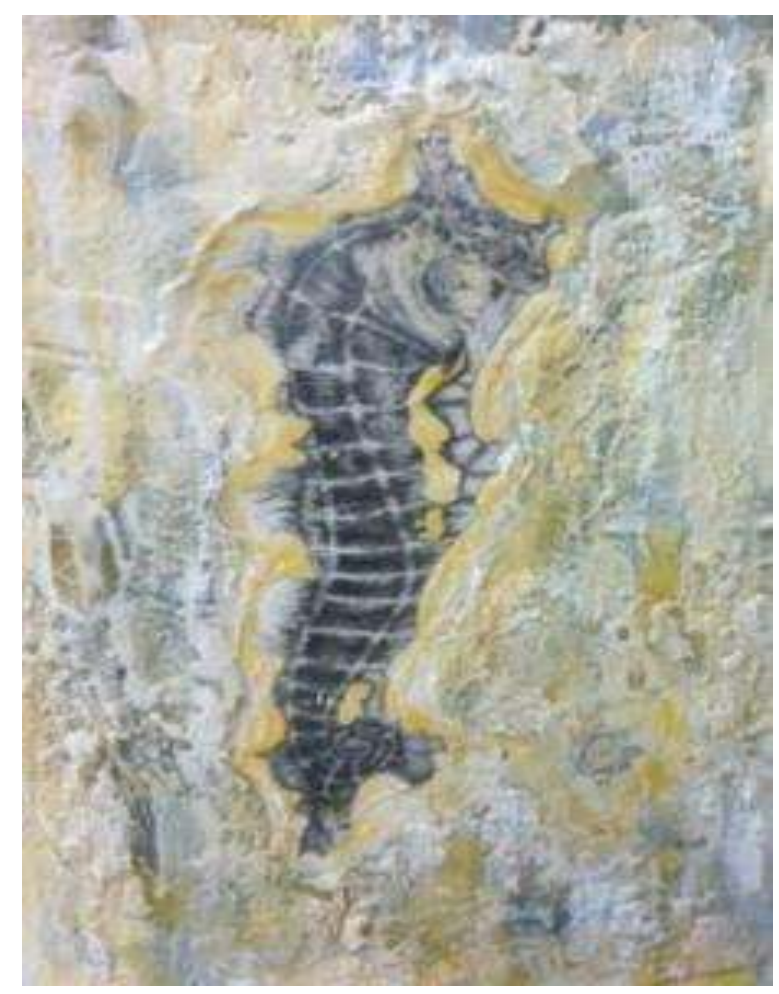

Figura 3: Ilha Flutuante I, 2014 Técnica: Encáustica - Foto e obra do autor Dimensões: $20 \times 30 \mathrm{~cm}$ Fonte: Acervo do autor

\section{Estudo da Técnica de Suminagashi}

É uma técnica japonesa de marmorização de papel, que usa tinta sumi-ê para se desenhar na água. Utilizam-se tintas específicas para marbling (tinta japonesa), nanquim e ecoline. Para fazer a impressão, papéis mais finos são os melhores, como papel japonês de fina gramatura e papel para sumi-ê. Também é possível usar papel para aquarela (o mais indicado é com gramatura alta) e papéis artesanais. O processo é simples, mas o material tem de ser adequado para obter-se bons resultados. Apresento o trabalho em que apliquei a técnica em papel aquarela, $200 \mathrm{~g} / \mathrm{m}^{2}$, sobre o desenho. 


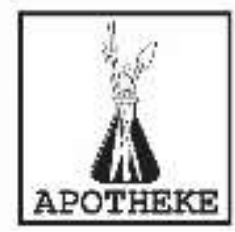

\section{Revista}

APOTHEKE

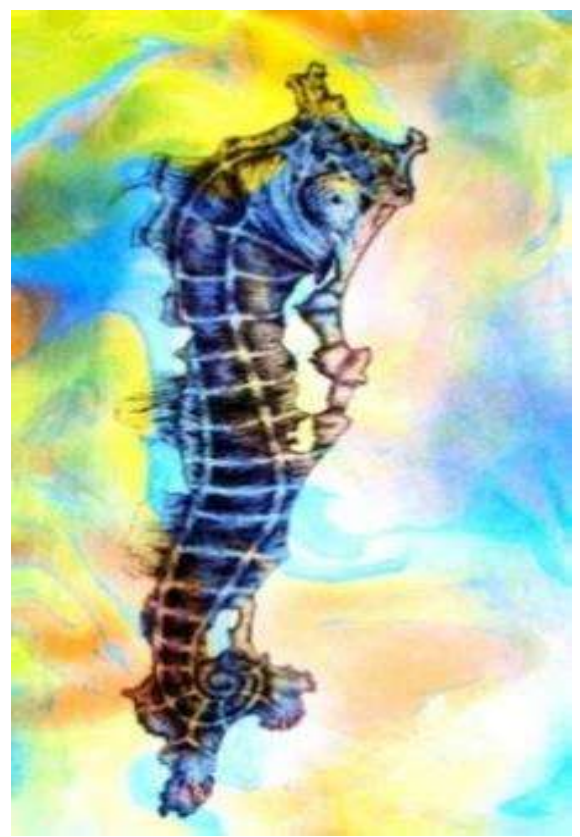

Figura 4: Ilha Flutuante II, 2014

Técnica: Suminagashi - Fotografia e obra do autor

Dimensões: $20 \times 30 \mathrm{~cm}$

Fonte: Acervo do autor

\section{e acrílica) \\ Estudo de pigmento: produção artesanal de tinta lóleo \\ Nesse estudo foi fornecida a lista de materiais} necessários e as referências para fazer artesanalmente a tinta a óleo e acrílica. Todo o processo foi desenvolvido de acordo com a orientação, desde a fragmentação dos pigmentos por molete para macerar, até a colocação das tintas nas bisnagas. Foi uma experiência única, que permitiu conhecer a fabricação das tintas, sobretudo fazêlas. Como utilizo sempre tinta a óleo, optei por essa produção.

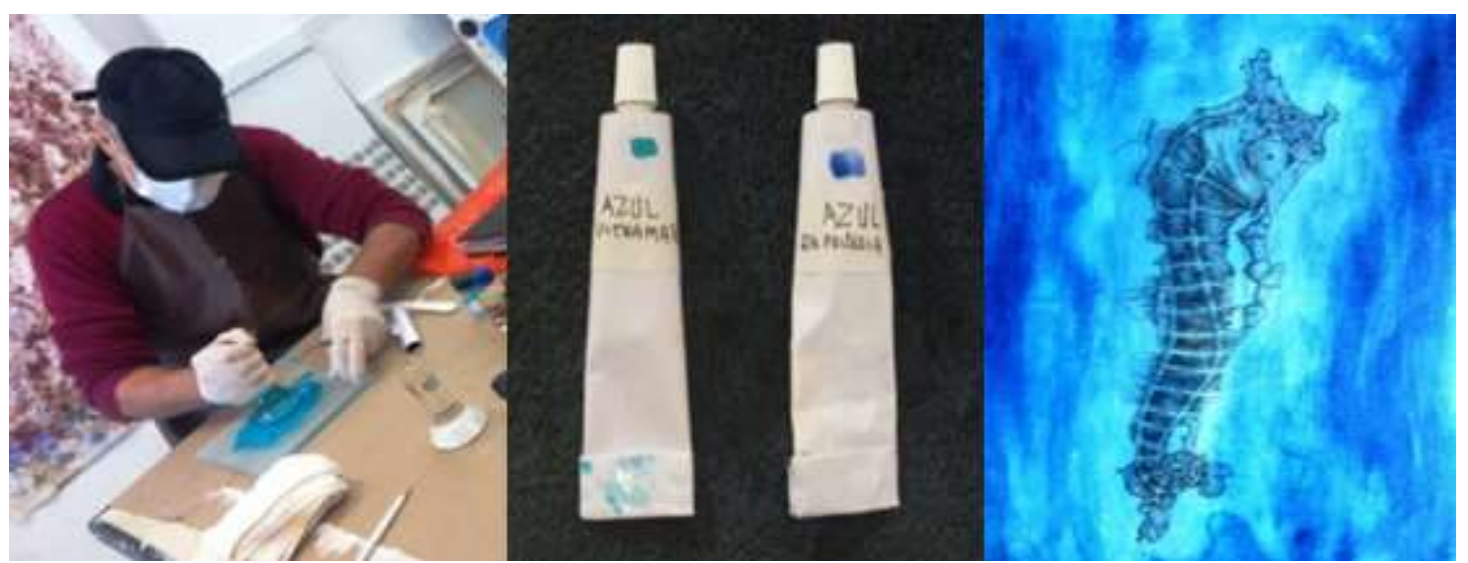

Figuraura 5 (A, B, C) : Preparação manual das tintas a óleo usando molete para trituração de pigmento; Embalagem da tinta fabricada; Pintura utilizando a tinta fabricada.

Trabalho: Ilha flutuante III, 2014.

Técnica: Tinta a óleo manufaturada.

Dimensões: $20 \times 30 \mathrm{~cm}$

Fonte: Acervo do autor - Fotografias e obra do autor. 


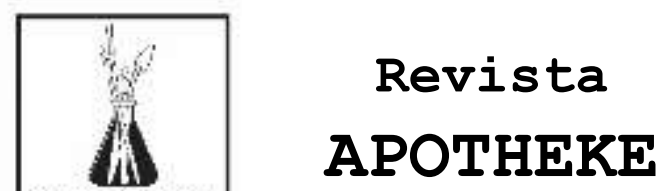

Uma das vantagens é que permite fazer tonalidades que nem sempre estão disponíveis para comprar no mercado. A composição e proporção dos elementos usados no processo de fabricação também são opções que manualmente pode-se fazer de acordo com o projeto artístico. São possibilidades acessiveis para obter-se uma tinta específica e genuína. A dificuldade é adquirir pigmentos, muitas vezes inacessíveis pela quantidade, preço ou qualidade. As figuras a seguir ilustram etapas dessa produção.

\section{Estudo de Técnicas de Têmpera}

Este é um estudo para fazer tinta com ovo. A receita foi baseada no livro Manual do Artista, de Mayer (2006, p. 296-301). Na experiência utilizaram-se clara e gema de ovo como componentes básicos da tinta, sendo adicionados pigmentos com diversos tipos de cores, e feita uma tabela para estudo. As tintas foram colocadas em vidros. Como experiência, além de fazê-las, testei as referidas tintas numa composição de uma paisagem feita numa tela preparada com gesso e impermeabilizada com cola de coelho. Uma das dificuldades foi o odor emitido proveniente da composição da tinta com ovos, além do prazo para usá-la. Apresento a pintura nessa técnica, conforme segue.

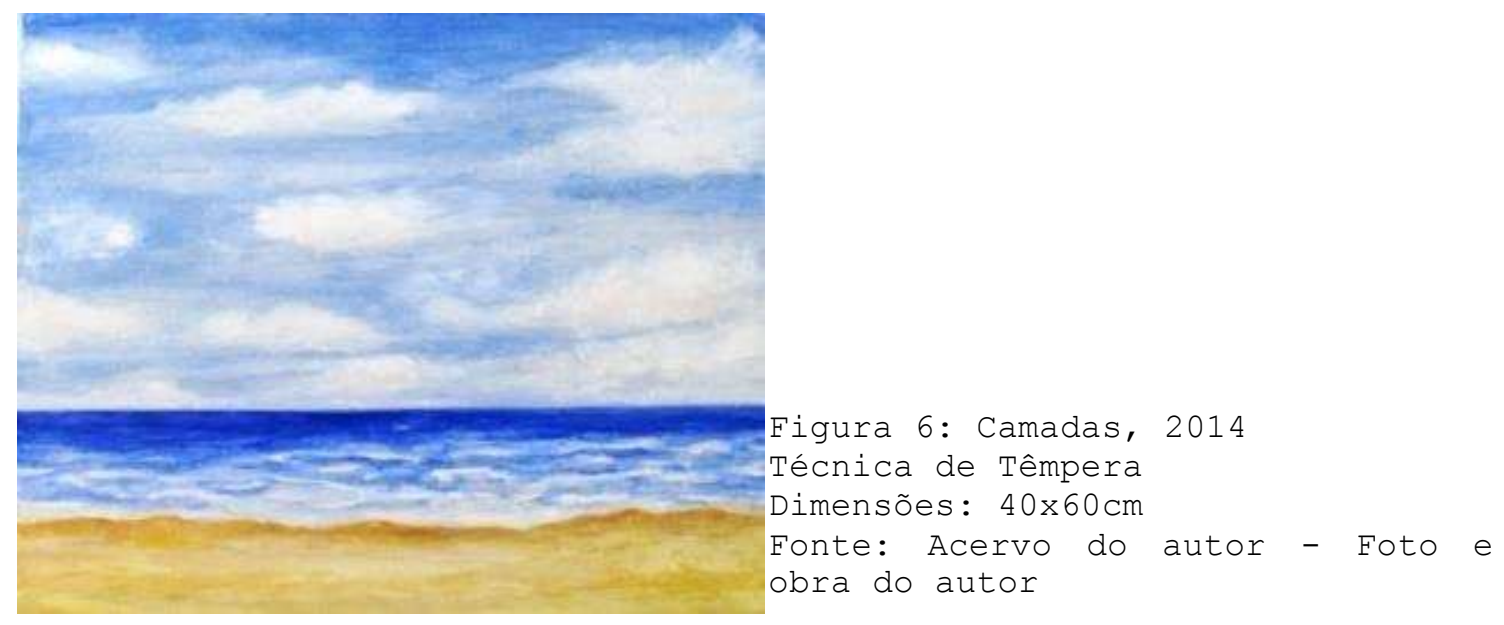

Além da prática das técnicas, concomitantemente vários estudos de artistas e suas obras (Wolf Kahn, Hugh O'Donnell, Teresa Poester, Guillermo Kuitca, Frida Kahlo, Edward Hopper, Hugh O'Donnell, Alex Katz) contribuíram significativamente para meu aprendizado artístico e conhecimento, bem como os encontros com os artistas Liliam Amaral, Lucimar Bello, Fernando Augusto, Teresa Poester, Frantz Soares, e as visitas aos ateliês da Prof. a Yara Guasque e do artista Rubens Oestroem. Entretanto, muitos outros artistas foram referenciados, pesquisados e 


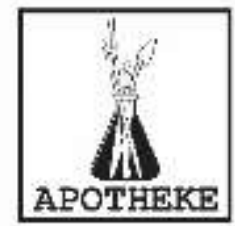

\section{Revista}

APOTHEKE

estudados, contribuindo para minha expansão da visão artística e poética.

O Estúdio de Pintura Apotheke proporciona esse horizonte de possibilidades, experiências e conhecimento para o aprimoramento do artista-professor e do professorartista. E esse caminho continua...!

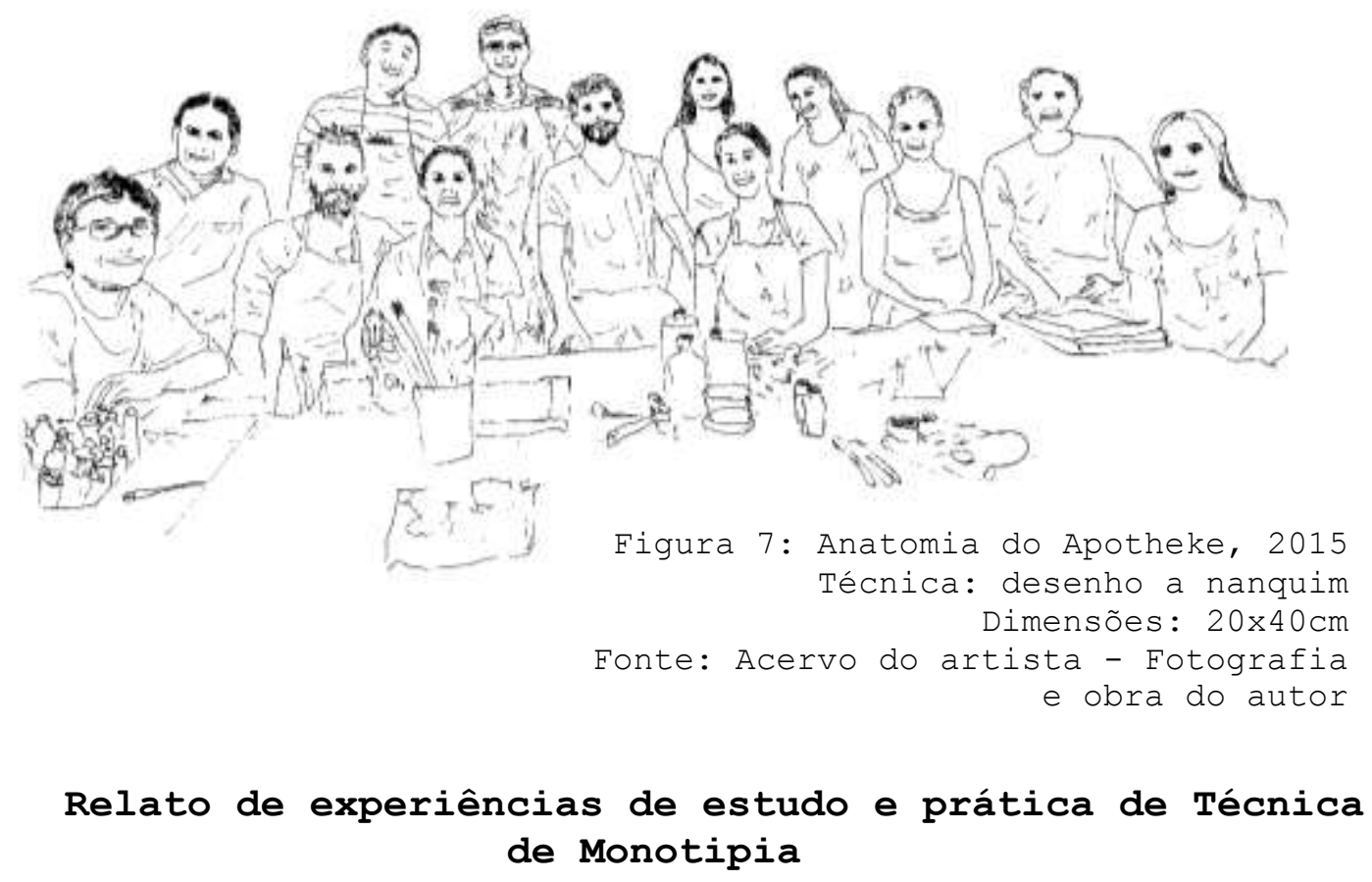

Saída de campo na disciplina "Sobre ser professor artista", PPGAV/UDESC

Professora: Dra . Jociele Lampert Dia: 03/12/14, quarta-feira Estudo de técnica monotipia usando tinta a óleo sobre vidro

Com relação à técnica de monotipia, primeiro temos que entender o que ela significa. Para Meyer, no seu Manual do artista, a monotipia ocupa um lugar intermediário entre as artes gráficas e a pintura (Meyer, 2006, p. 660). A princípio, é uma técnica de gravura, ou seja, um processo de imersão/impressão de uma pintura a óleo feita sobre um vidro e transferida para o papel. Em uma rápida consulta no site Google sobre monotipia é possível sabermos que essa técina originou-se no séc. XVII, com Giovanni Benedetto Castiglione (1616-1670). Trata-se de um processo de impressão artística por meio do qual se transfere, por pressão, uma pintura em uma superfície lisa, como um vidro, placa de plástico/acrílico, cobre ou metal, para o papel. 


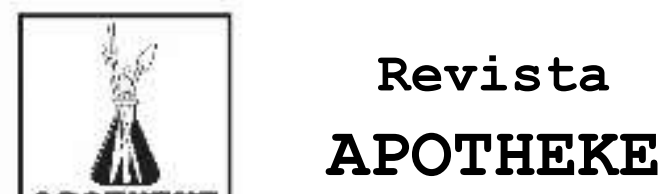

Cada impressão é única, tendo em vista que o óleo sobre o vidro vai aderindo ao papel a cada tiragem, resultando em uma nova cópia com menor intensidade e visibilidade em relação à primeira cópia. Mesmo refazendo a pintura do vidro, existe sempre a diferença entre as cópias.

Relato minha experiência referente à saída de campo propiciada pela Professora Jociele na disciplina "Sobre Ser Professor Artista" para o estudo da técnica de monotipa, usando tinta a óleo sobre uma placa de vidro, papel japonês e aquarela. Antes de fazer o processo, a professora nos havia passado uma lista de materias para suporte e realização da técnica e indicado um artista de referência, conforme segue.

Lista de materiais: paleta, pincéis diversos, espátulas, tinta óleo, giz pastel oleoso, terebintina ou outro solvente, placa de acrílico ou placa de vidro (tamanho A4, maior ou como desejar); barém ou rolo de gravura ou colher de pau; papel de gramaturas diversas (japonês é o mais indicados, ou preferencialmente mais finos - os de maior gramatura são aconselhados para impressão em prensa); impressão fotográfica de boa qualidade ( $\mathrm{PB}$ ou colorida) do tema que você pesquisa ou imagem de livro que você usa como referência na sua pesquisa. É solicitado que cada aluno leve sua imagem (preferencialmente que seja relacionada com sua pesquisa), paleta, pincéis e tintas que vai usar na imagem.

Artista de referência: Wolf Kahn (ver site e vídeo):

$<$ http://www.wolfkahn.com>

<https://vimeo.com/15130724> <https://vimeo.com/77727977>

Com base nas instruções recebidas, levei todo o material solicitado, bem como algumas imagens que gostaria de trabalhar. Também assisti aos vídeos recomendados, bem como de outros artistas que trabalham com essa técnica. No primeiro encontro, fiz várias imagens de paisagens abstratas. Foi minha primeira experiência com essa técnica de monotipia a óleo, fazendo uma pintura sobre uma placa de vidro e imprimindo em papel japonês e em papel para aquarela $150 \mathrm{~g} / \mathrm{m}^{2}$. A metodologia é simples, fácil de ser aplicada, e o resultado é instantâneo. Pinta-se primeiro a imagem desejada sobre o vidro, que pode ser imaginada, ou pode-se colocar sob o vidro a imagem escolhida como referência. Depois, coloca-se o papel sobre a base pintada do vidro e, por pressão com uma colher de madeira, ou barém, faz-se a transferência. Após, retirar o papel, devese colocá-lo para secar.

o processo em si permite que se obtenha mais de uma cópia com intensidades diferentes, uma vez que a tinta vai diminuindo a cada impressão realizada. A secagem do papel é o processo que exige maior tempo. 


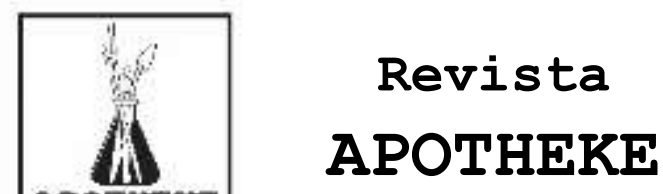

Uma das dificuldades encontradas foi a utilização de papel japonês, devido à sua espessura muito fina. É melhor usar um papel com espessura maior. O papel para aquarela não apresentou problema por ser de maior gramatura, embora sua absorção e secagem sejam mais lentas. Outra dificuldade inicial foi a utilização de uma fina espessura de tinta óleo e excesso de secante, que prejudicou a impressão pelo fato de secar muito rápido e pela demora em fazer a imagem. Refiz com mais espessura de tinta a óleo e menos secante, conseguindo um bom resultado. Como exemplo, identifico, por meio das imagens abaixo, o resultado alcançado nesse primeiro encontro.
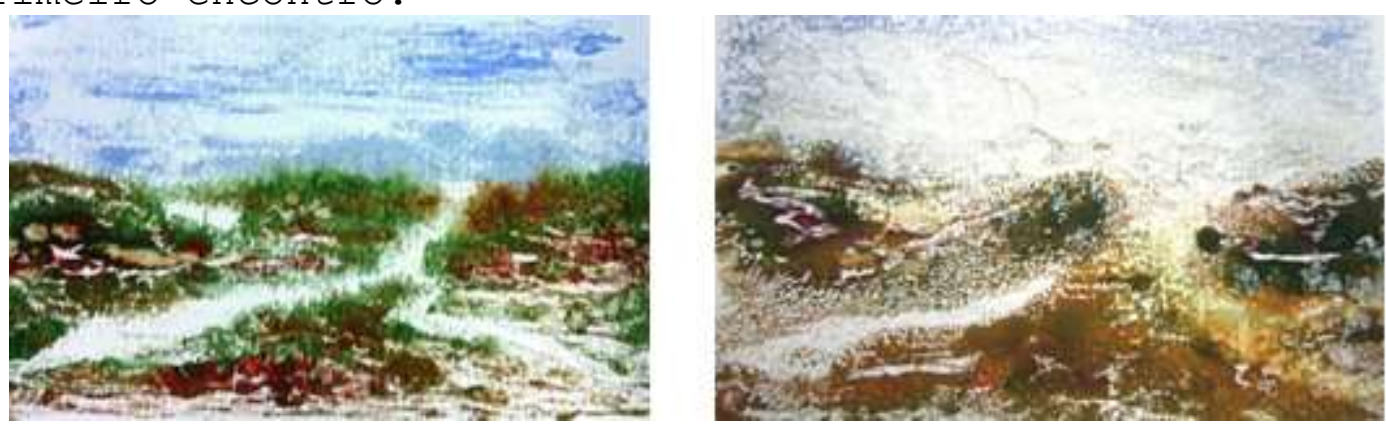

Figura 8 (A, B) : Verão I e Verão II

Monotipia: $1^{\mathrm{a}}$ e $2^{\mathrm{a}}$ impressão em papel aquarela

Dimensões: $20 \times 30 \mathrm{~cm}$

Fotografias e obras do autor, 2014

Fonte: Acervo do artista

Figura 9: Verão III

Monotipia: $3^{a}$ impressão em papel aquarela

Dimensões: $20 \times 30 \mathrm{~cm}$

Fotografia e obra autor, 2014

Fonte: Acervo do autor

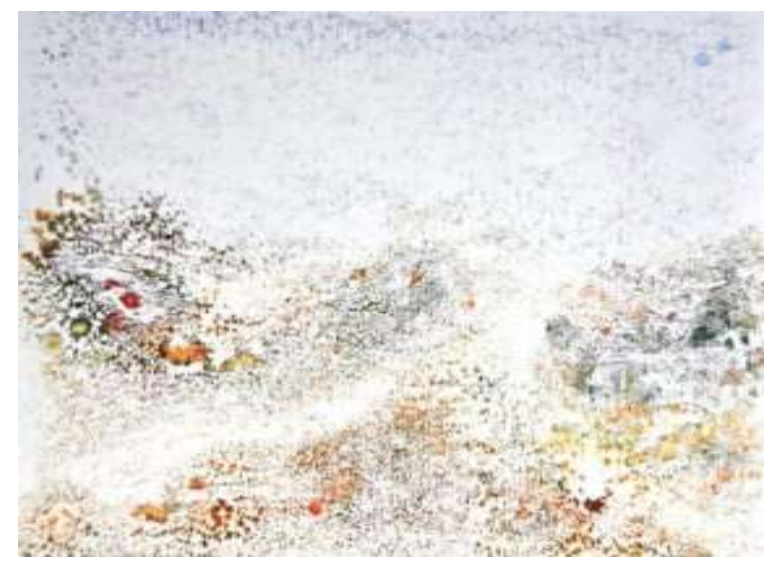

Observa-se que, a cada tiragem da matriz, a imagem vai ficando com menos visibilidade em relação à imagem inicial. São resultados diferentes, mas que trazem uma poética interessante, uma vez que é uma derivação da imagem inicial da matriz, e que só é possível ver quando se repete o processo, colocando um novo papel para uma nova cópia da imagem inicial. Outro exemplo da técnica de monotipia, em papel japonês: 


\section{Revista \\ APOTHEKE}
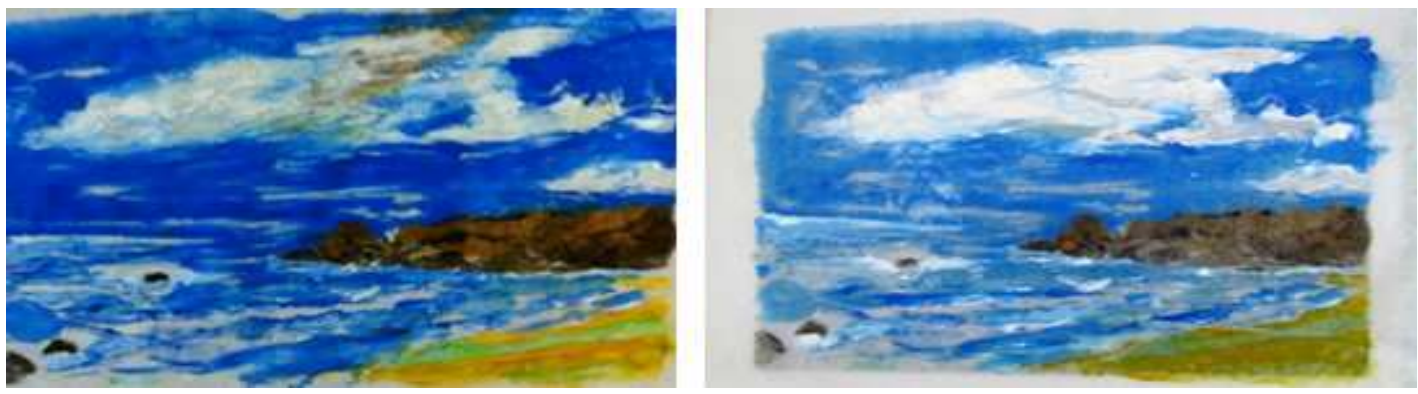

Figura 10 (A, B) : Praia Solidão I, II

Monotipia: $1^{a}$ e $2^{a}$ impressão em papel japonês

Dimensões: $20 \times 30 \mathrm{~cm}$

Fotografias e obras do autor, 2014

Fonte: Acervo do artista

No segundo encontro, já com mais experiência, foi mais tranquilo o domínio da técnica. Foi revisto todo o processo, desde a parte teórica e a experiência adquirida no primeiro encontro. Levei algumas imagens afetivas, sendo uma do meu pai, da qual foram tiradas duas impressões em papel japonês. A secagem foi mais trabalhosa devido à quantidade de tinta, em excesso, que fez com que parte de uma das impressões acabasse aderindo ao suporte de secagem. O problema reincidente foi a fina espessura do papel japonês, que dificultou sua fixação no suporte para secagem. O ideal seria pendurá-las como em um varal, mas só é possível quando se utiliza um papel de gramatura maior, já que o que eu usei, por ser muito fino, apresentava o risco de rasgar. Por meio das imagens a seguir, apresento a $1^{a}$ e a $2^{a}$ impressão. Nota-se que a imagem vai sendo alterada, ficando cada impressão diferente uma da outra, tanto a matriz como a impressão.
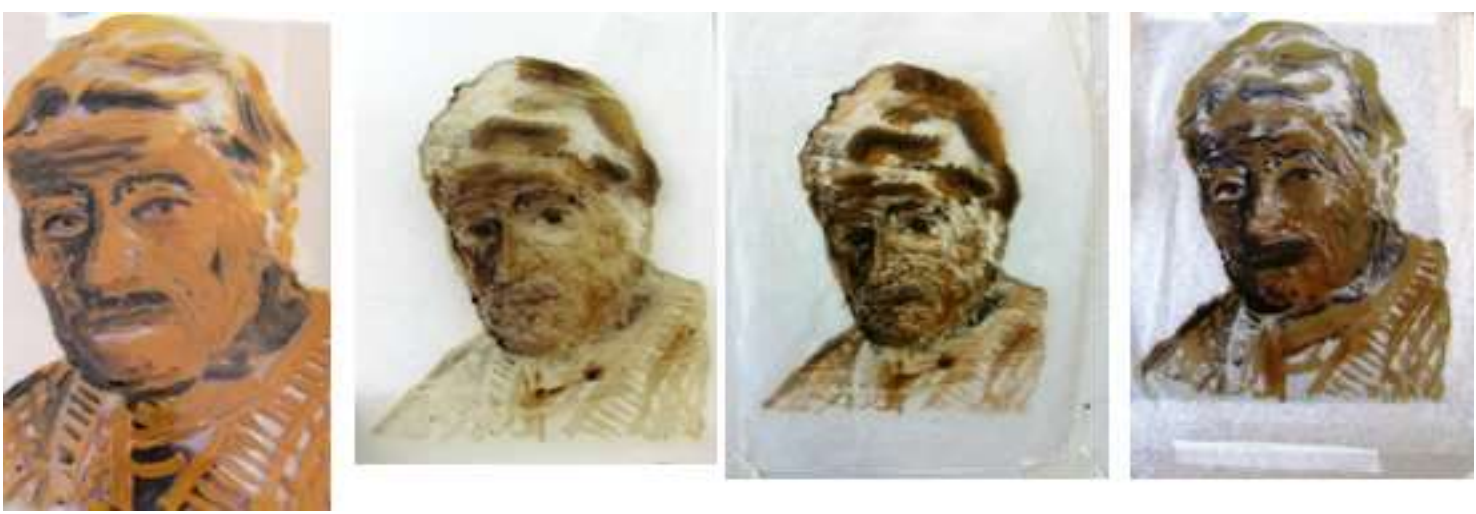

Figura $11 \quad(\mathrm{~A}, \mathrm{~B})$ : Pintura a óleo sobre o vidro para $1 .{ }^{a}$ e 2. ${ }^{a}$ reprodução de cianotipia Dimensões: $20 \times 30 \mathrm{~cm}$

Fotografias e obras do autor, 2014

Fonte: Acervo do artista.
Figura 12 (A, B) : Retrato I, II Monotipia: $1^{a}$ e $2^{a}$ impressão em papel japonês sobre a matriz Dimensões: $20 \times 30 \mathrm{~cm}$

Fotografias e obras do autor, 2014 Fonte: Acervo do artista 


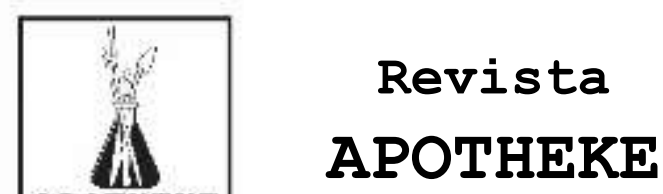

Essa técnica de monotipia é uma das várias possibilidades existentes entre as derivações com outras tintas, pigmentos, misturas de materiais, suportes e papéis. Com essa experiência, muitos trabalhos podem ser executados sem precisar de muitos elementos, propiciando a todos desenvolverem suas próprias poéticas.

\section{Relato de experiências de estudo e prática de Técnica de Cianotipia}

Saída de campo na disciplina "Sobre Ser Professor Artista", PPGAV/UDESC

Professora: Dra . Jociele Lampert Dia: 29/10/14, quarta-feira Estudo de técnica cianotipia

Com relação a essa técnica, que difere da monotipia, é um método de cópia fotográfica baseado na propriedade que têm certos sais de ferro que, sob a ação da luz, colorem-se em azul da Prússia. É usado para a reprodução de desenhos a traço, plantas e mapas. A cianotipia difere das fotografias fixadas em prata, fotos em PB, pois utiliza em sua fórmula sais de ferro. Estes são sensíveis à luz UV. Essa descoberta devemos a Sir John Herschel que, em 1842, desenvolveu a fórmula básica da cianotipia.

Antes da saída de campo, a professora nos deu orientações e referências bibliográficas para consulta e pesquisa e a lista de materiais: imagem impressa em acetato/papel transparência em PB; imagem de filmes antigos de fotografias não revelados; folhas e objetos que podem ser prensados. Papel para aquarela (de boa gramatura); prendedores de roupa ou para pressão; acrílico ou vidro do mesmo tamanho do papel ou menor; pincéis limpos; panos para limpeza; plástico ou saco plástico transparente; potes, colheres ou pipetas; bacia para revelação; água destilada. Químicos: solução A: $25 \mathrm{~g}$ de citrato férrico aminiacal verde + 100ml de água destilada; solução B: $10 \mathrm{~g}$ de ferricianeto de potássio + 100ml de água destilada. Misturar partes iguais (duas colheres de acordo com o tamanho do papel), aplicar na superfície do papel, inserir a imagem, colocar sobre o vidro ou acrílico e gerar pressão; colocar em exposição solar por 30 minutos ou mais. Posteriormente, lavar em bacia para retirar o excesso de azul e deixar secar.

Sites para consulta:

<http://prezi.com/-zpvpuivk65p/...>

<http://www.getty.edu/.../pdf_publicat.../pdf/atlas_cyanotype.p $\mathrm{df}>\langle$ http://www. youtube. com/watch?v=9q8N_KgH8SI $\overline{>}$ 


\section{A $\begin{gathered}\text { Revista } \\ \text { APOTHEKE }\end{gathered}$}

A professora disponibilizou bacias, químicos, luvas. Pediu para levarmos papéis, imagens, pincéis e material de limpeza. As imagens deveriam fazer referência ou estarem articuladas com a pesquisa de cada um.

Conforme consulta realizada na internet sobre a técnica de cianotipia, sua fórmula básica, desenvolvida por Herschel, continua atual.

\section{Fórmula de Herschel:}

25 gramas de citrato de amônio férrico verde (ou vermelho); 10 gramas de ferricianeto de potássio (ou vermelho); Água destilada ou deionizada.

\section{Como fazer:}

1. Dilua a $25 \mathrm{~g}$ de citrato de amônio férrico em $100 \mathrm{ml}$ de água - guarde em um frasco escuro.

2. Dilua $10 \mathrm{~g}$ de ferrocianeto de potássio em $100 \mathrm{ml}$ de água - guarde em um frasco escuro.

3. Misture as duas substâncias em partes iguais. Use essa mistura no suporte, que pode ser papel ou tecido.

4. Quando for aplicar no papel, empregue moderadamente sem encharcá-lo.

5. Deixe o papel secar no escuro.

6. Após seco, coloque o papel e o seu fotograma entre duas placas de vidro, exponha ao sol. O tempo de exposição varia de acordo com a intensidade da luz.

7. Quando o papel mudar de cor - ficará cinza - retire do sol, levante o negativo, lave em água corrente até sair todo o verde amarelado, que é o resíduo do cianeto.

8. Pendure o papel no varal na sombra.

Atenção! Mesmo que os químicos empregados apresentem baixa toxidade, previna-se: use luvas, máscara, óculos e avental.

\section{Material}

1. 25 gramas de citrato de amônio férrico (verde ou vermelho);

2. 10 gramas de ferricianeto de potássio;

3. Água destilada ou deionizada;

4. Colheres de plástico para medir;

5. Jarro com medição;

6. Frascos de vidro para misturar;

7. Colheres de plástico;

8. Luvas de borracha, máscara;

9. Avental ou camiseta velha;

10. Jornal para cobrir superfície de trabalho;

11. Pano de limpeza;

12. Pincéis - que serão descartados; 


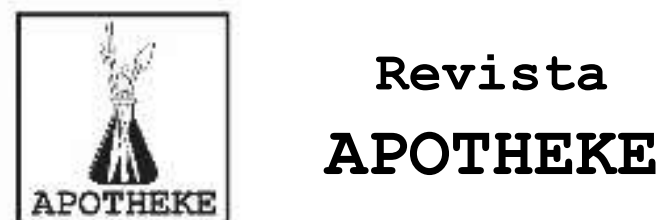

13. Prendedor de roupa no varal - de plástico;

14. Varal;

15. Papel Canson linha estudante $200 \mathrm{~g} / \mathrm{m}^{2}$;

16. Duas placas de vidro para impressão do contato;

17. Luz do sol (essencial).

Sites para consulta:

<www.alternativephotography.com/wp/processes/cyanotype> <http: / / www.alternativephotography.com/wp/processes/cyanoty pe/beat-the-blues-making-cyanotypes> (Esse link é especial, mostra passo a passo todo o processol <http://wikipedia/commons/e/e2/Anna_Atkinse>

Com as orientações recebidas e com os materiais necessários para aplicar a técnica de cianotipia, iniciouse o processo por etapas. No início, surgiram muitas dúvidas, mas foram sendo esclarecidas à medida que o processo ia sendo elaborado. As primeiras experiências foram com diversas folhas de vegetais e com o negativo de diversos autorretratos. Ambas as experiências tiveram resultados satisfatórios. Foi seguida toda a orientação da técnica: misturados os produtos na proporção recomendada, de acordo com a preparação da fórmula pronta elaborada pela Professora e disponibilizada para todos os alunos. Na primeira experiência, foi aplicada a solução química sobre o papel com um pincel, e depois se esperou secar. Depois de seco, foi colocado o negativo das imagens de autorretrato sobre ele, e em seguida colocado entre duas placas de vidro. Para os vidros não se deslocarem, este foi fixado por fitas nas bordas. Em seguida, levado ao sol. Depois de trinta minutos, foi retirado e levado para lavagem para retirada dos resíduos de cianeto.

A princípio, a imagem não fica visível, só aparece aos poucos, à medida que se vai lavando. O azul da prússia vai aparecendo e a cor marrom-amarelada (cianeto) vai saindo a medida que o papel é lavado com água. Em seguida, coloca-se - papel para secar.

Foram feitas várias experiências. As primeiras não ficaram boas: as imagens ficaram claras demais devido ao pouco tempo exposto ao sol ou à pouca aplicação da solução química. Na segunda experiência foram usadas, no lugar do negativo, folhas de vegetais, que funcionam como um negativo, e permitiram uma imagem nítida da sombra impressa pela luz do sol. Essas duas experiências estão ilustradas nos exemplos das imagens a seguir. 


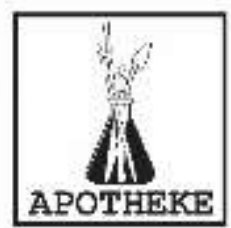

Revista

APOTHEKE
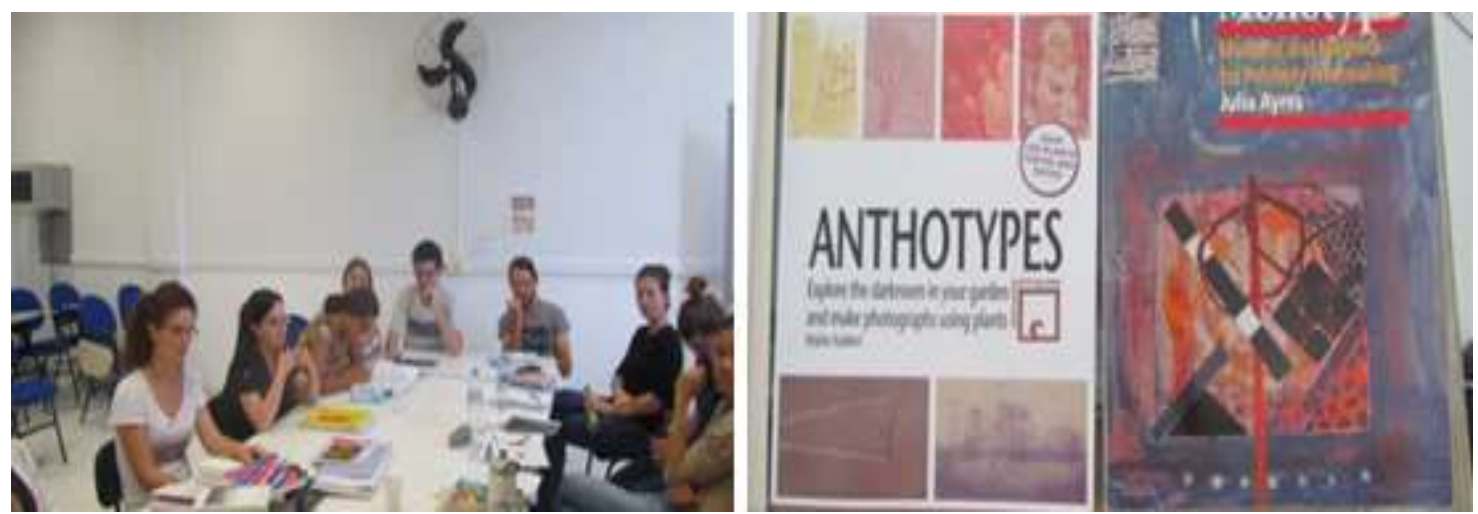

Figura 13 (A, B): Orientações e referências dadas pela Professora Jociele.

Fotografias do autor, 2014

Fonte: Acervo do autor
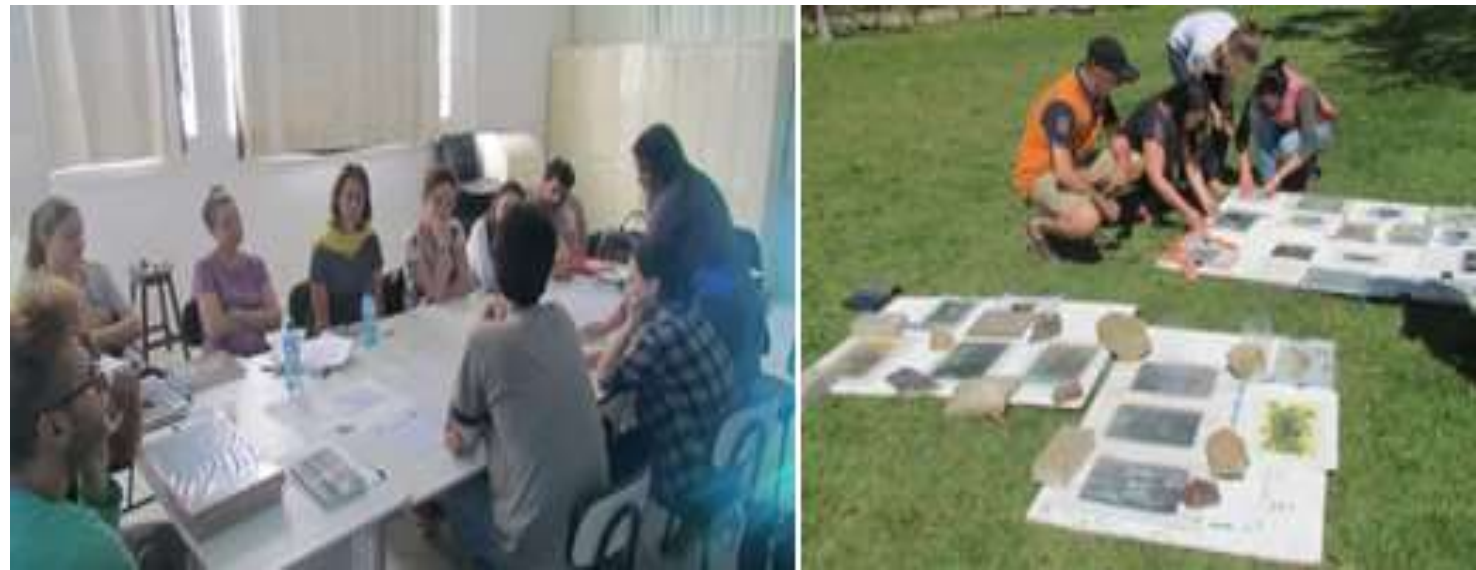

Figura 14 (A, B): Explicações e colocação dos trabalhos no sol. Fotografias do autor, 2014 Fonte: Acervo do autor

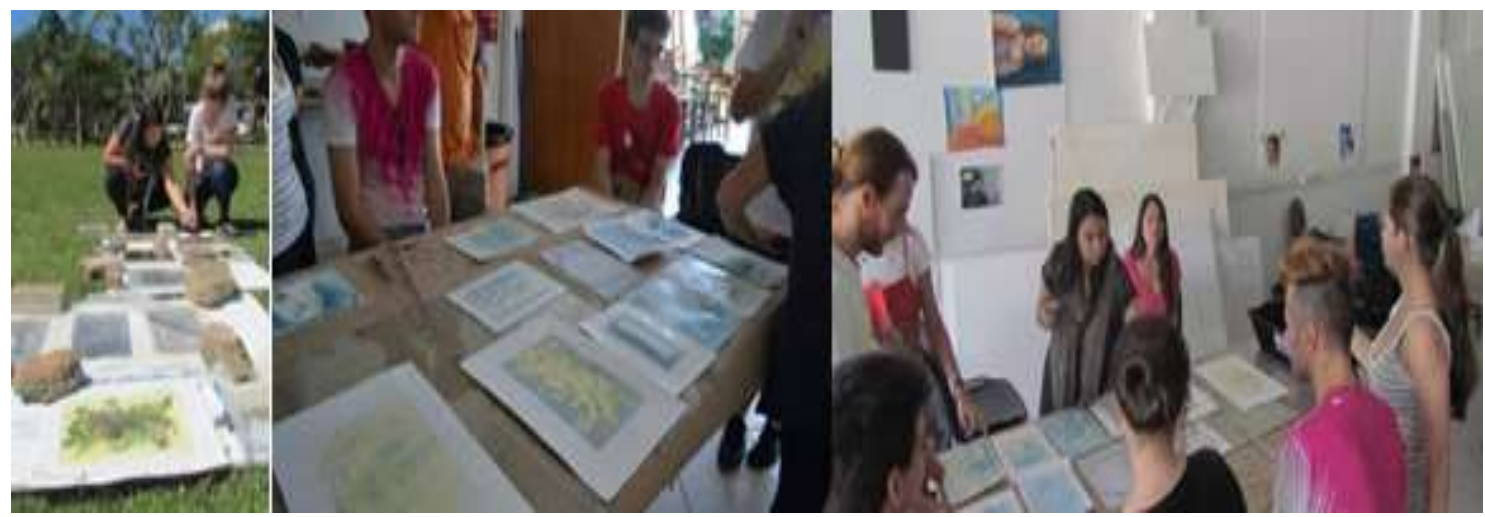

Figura 15 (A, B, C) : Trabalhos colocados no sol e apresentados para apreciação e avaliação. Fotografias do autor, 2014 Fonte: Acervo do autor 


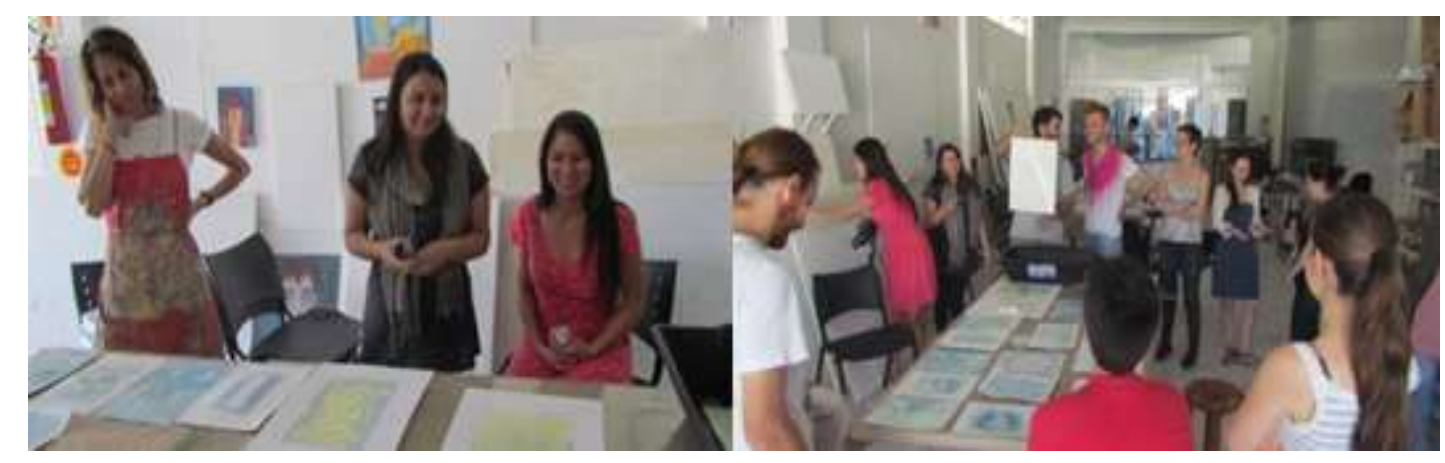

Figura 16 (A, B): Trabalhos apresentados para apreciação e avaliação dos alunos Fotografias do autor, 2014

Fonte: Acervo do autor
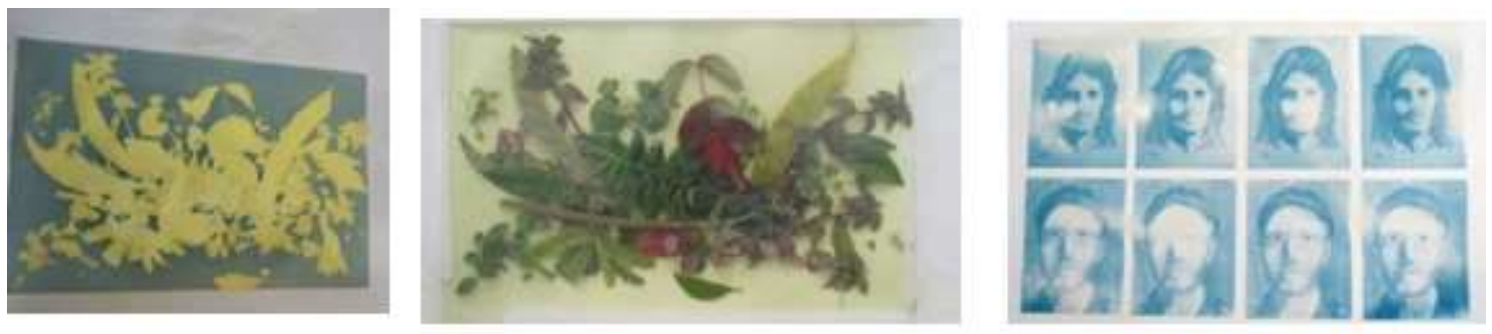

Figura 17 (A, B, C) : Resultado da experiência do autor Fotografias do autor, 2014.

Fonte: Acervo do autor

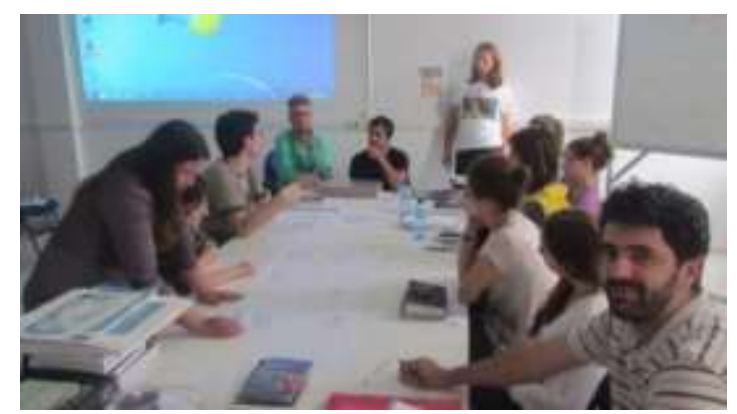

Figura 18: Avaliação final da aplicação da técnica de cianotipia e troca de experiência. Fotografias do autor, 2014. Fonte: Acervo do autor

Com base na experiência obtida na saída de campo da disciplina "Sobre Ser Professor Artista", a prática de cianotipia, procurei aperfeiçoar a técnica e melhorar os resultados obtidos.

A professora disponibilizou para todos a solução química para fazerem experiências em seus ateliês. Isso propiciou novas experiências e aprimoramento da técnica para além da aula da disciplina.

Procurei então, escolher novas imagens que se relacionassem com meu trabalho. Parti dos retratos e autorretratos que foram pintados e desenhados. Escolhi dois a óleo e dois a lápis HD/Nanquim, totalizando quatro: o 


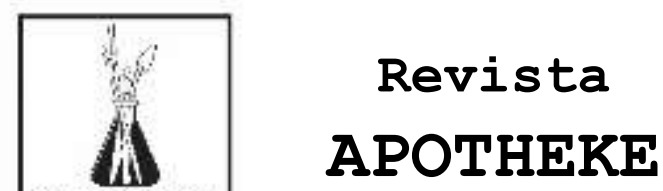

primeiro da minha esposa, o segundo da minha filha, o terceiro e quarto, meus autorretratos.

Segui todos os passos que aprendi e desenvolvi mais alguns pela experiência e observação. Ressalto que desde a escolha do papel até a secagem foi grande um aprendizado. o papel utilizado foi Fabrian $200 \mathrm{~g} / \mathrm{m}^{2}$; o negativo de acetato $\mathrm{PB}$ foi feito com impressora a jato de tinta (não usar a laser); as fitas adesivas foram fixadas nas bordas do papel; considerando as medidas do negativo da imagem; a solução química foi passada no papel dentro de um ambiente escuro feito provisoriamente no closed de roupa; o papel ficou secando no escuro até o seu uso (assim evita formação de vapor e marcação no vidro, que prejudica a imagem); o tempo suficiente para esta secagem foi indicado pela variação da cor cinza; foi melhor usar a inclinação do sol das $10 \mathrm{~h}$ às 15h; usou-se sempre papel jornal como suporte das placas de vidro; para evitar que a água corrente caísse sobre a imagem no momento de lavagem da canotipia, foi usado um recipiente para fazer a imersão do papel na água; - papel foi estendido na sombra para secar, preferencialmente na horizontal para não escorrer nas laterais e evitar manchas; retirou-se as fitas 3M demarcatórias somente depois do papel estar quase seco, evitando assim o surgimento de manchas; o papel ficou sobre uma superfície lisa, descansando, para secar e evitar ondulações; quando colocada em quadro, procurou-se não encostar a imagem no vidro, fazendo uso do passe-partout. Nas imagens relacionadas abaixo, são visualizadas algumas etapas desse processo.

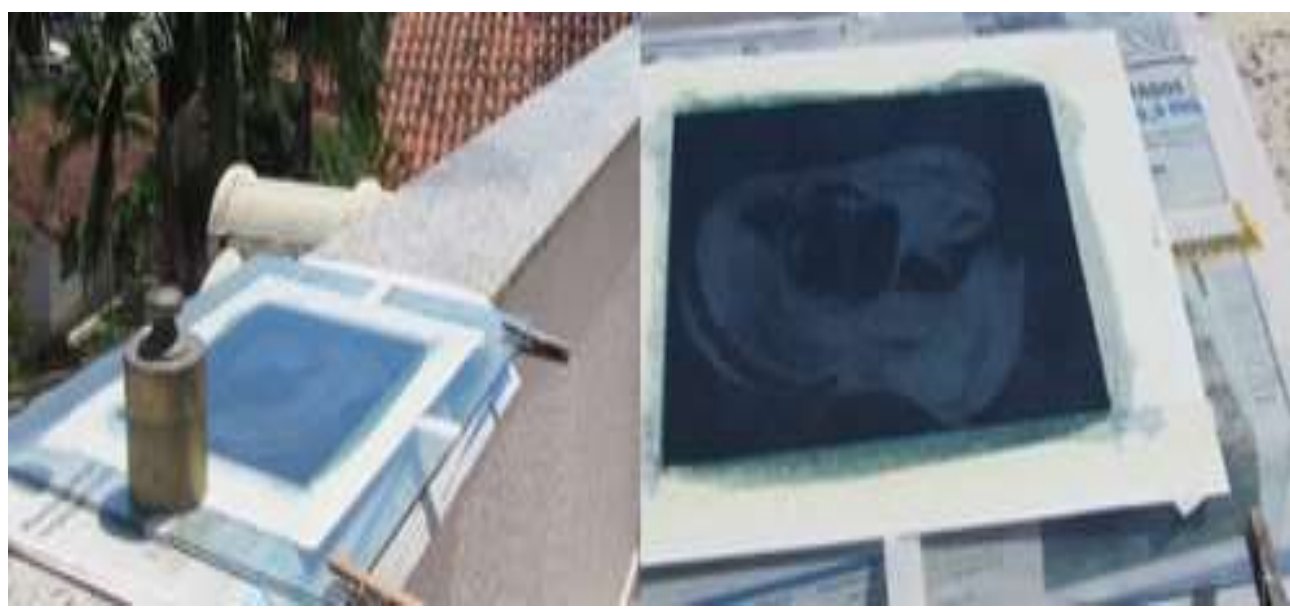

Figura 19 (A, B) : Montagem do processo de cianotipia colocado ao sol. Fotografias e obra do autor, 2014. Fonte: Acervo do artista 


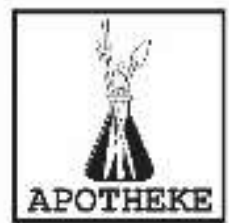

Revista

APOTHEKE
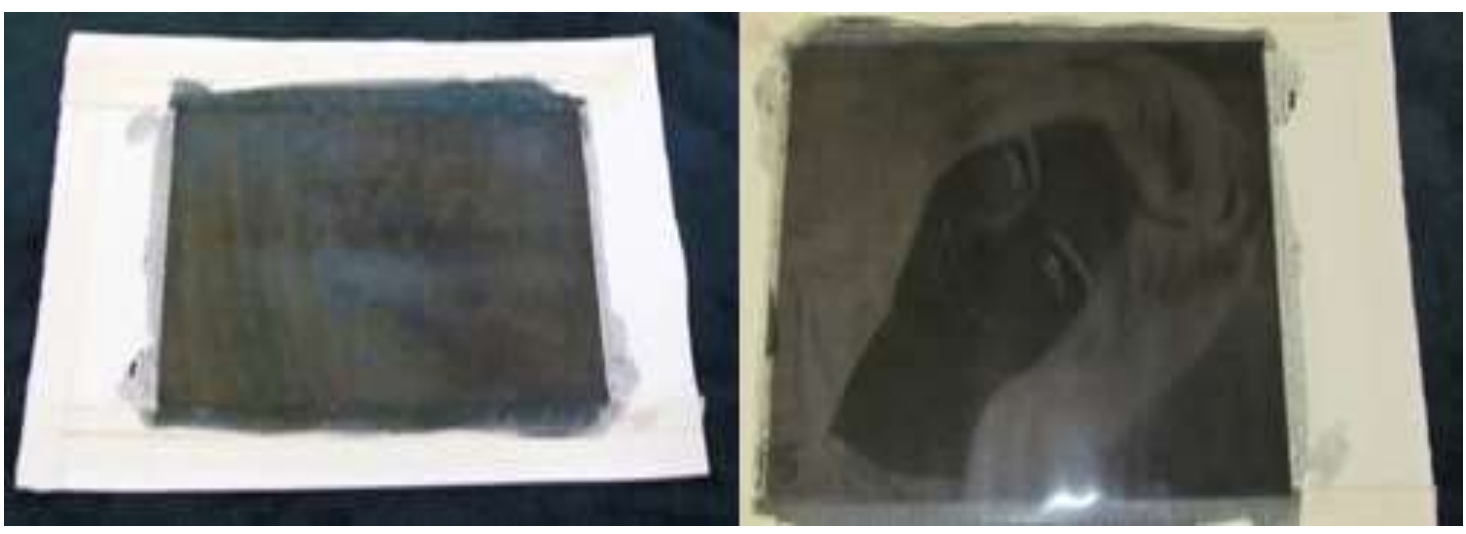

Figura 20 (A, B): Processo com 0 negativo sob o sol; retirado o negativo após o tempo de 30 minutos.

Fotografias e obra do autor, 2014.

Fonte: Acervo do artista

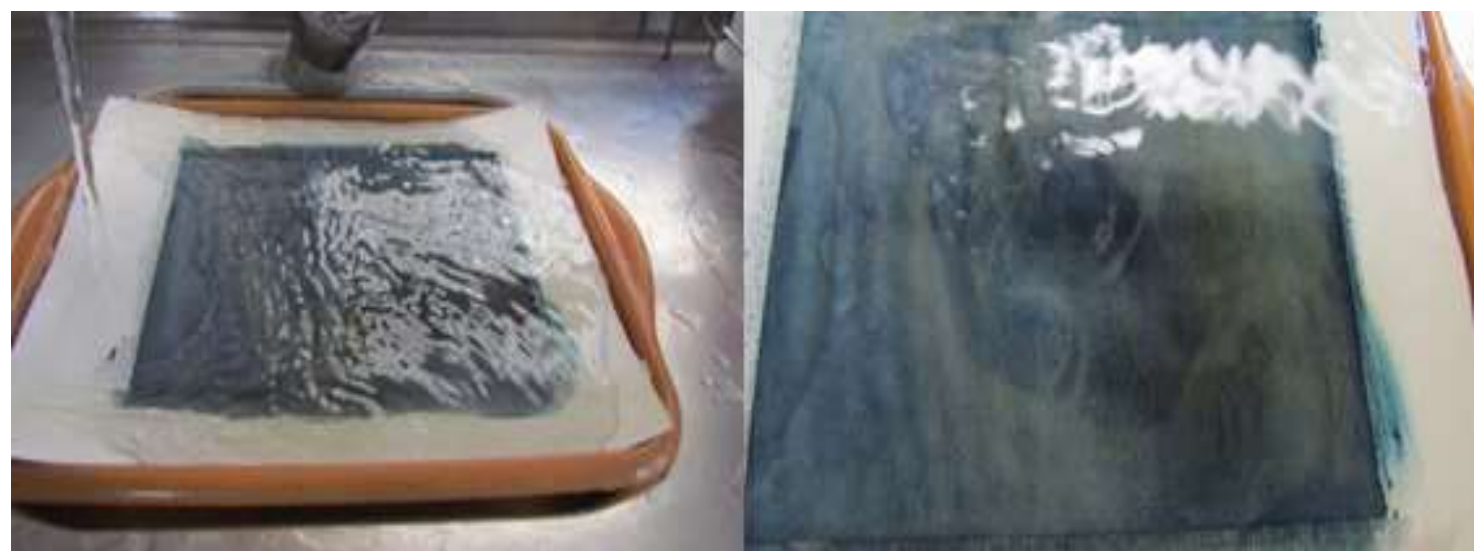

Figura 21 (A, B) : Colocação sob água corrente: a imagem vai aparecer aos poucos.

Fotografias e obra do autor, 2014.

Fonte: Acervo do artista

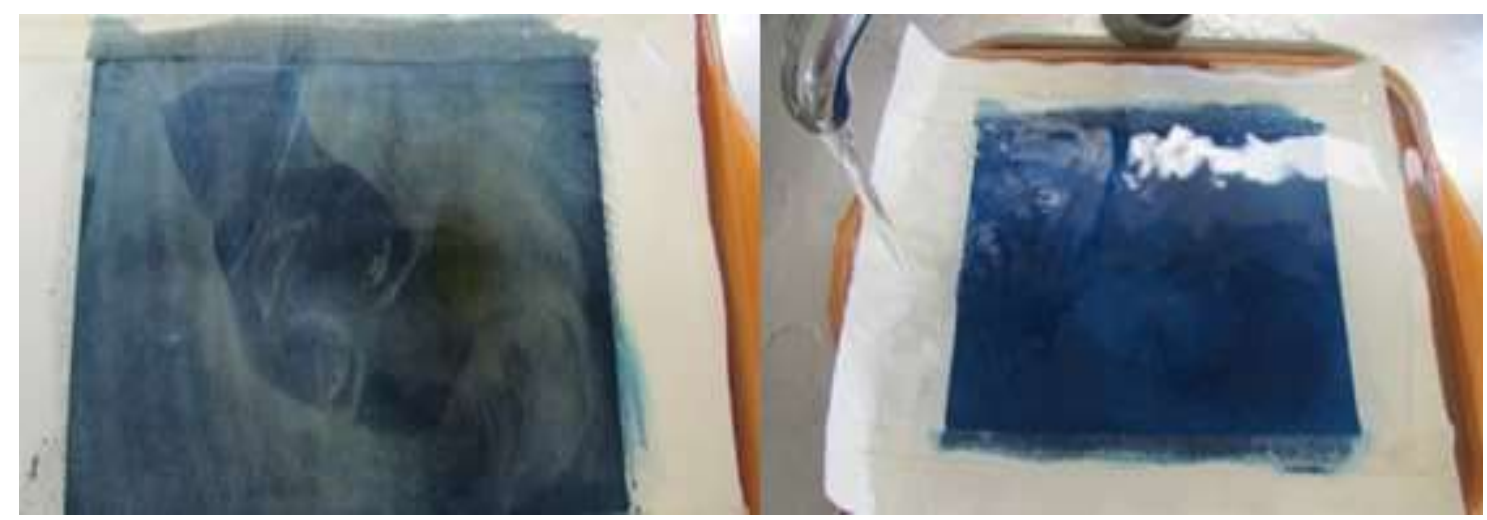

Figura 22 (A, B) : Observar a presença de cianeto pela cor marron-amarelado até sua retirada total.

Fototografias e obra do autor, 2014. 

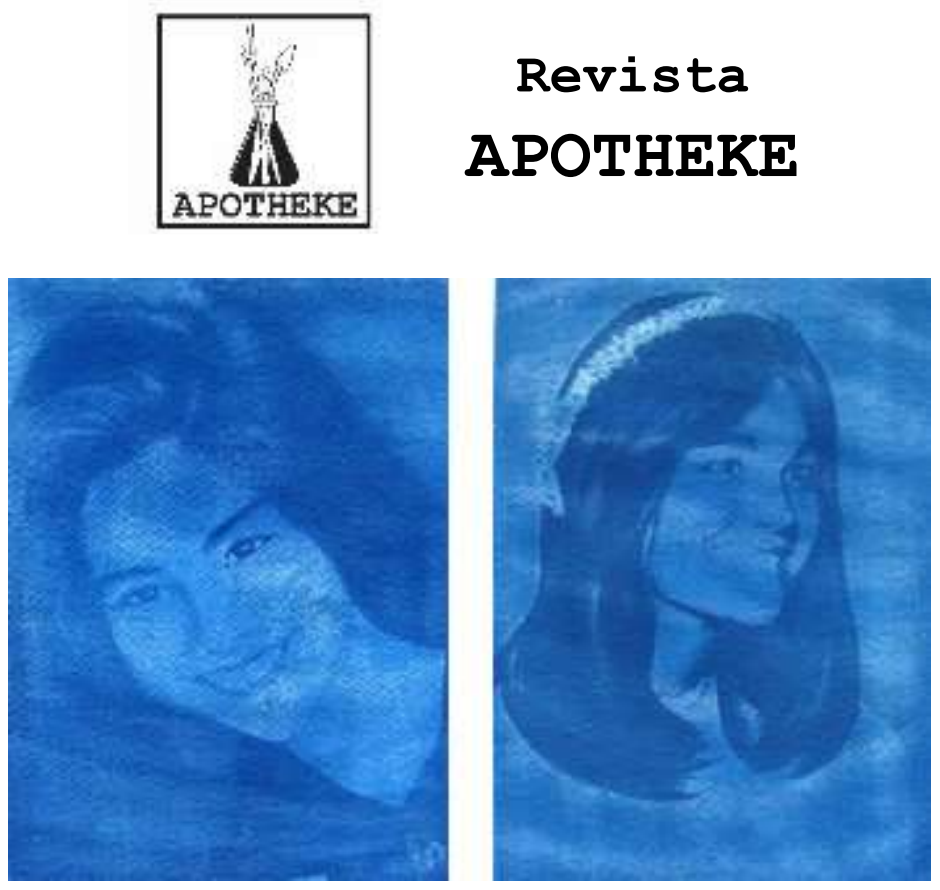

Figura 23 (A, B) : Processo da remoção do cianeto finalizado, pronto para secagem.

Fotografias e obra do autor, 2014.

Fonte: Acervo do artista
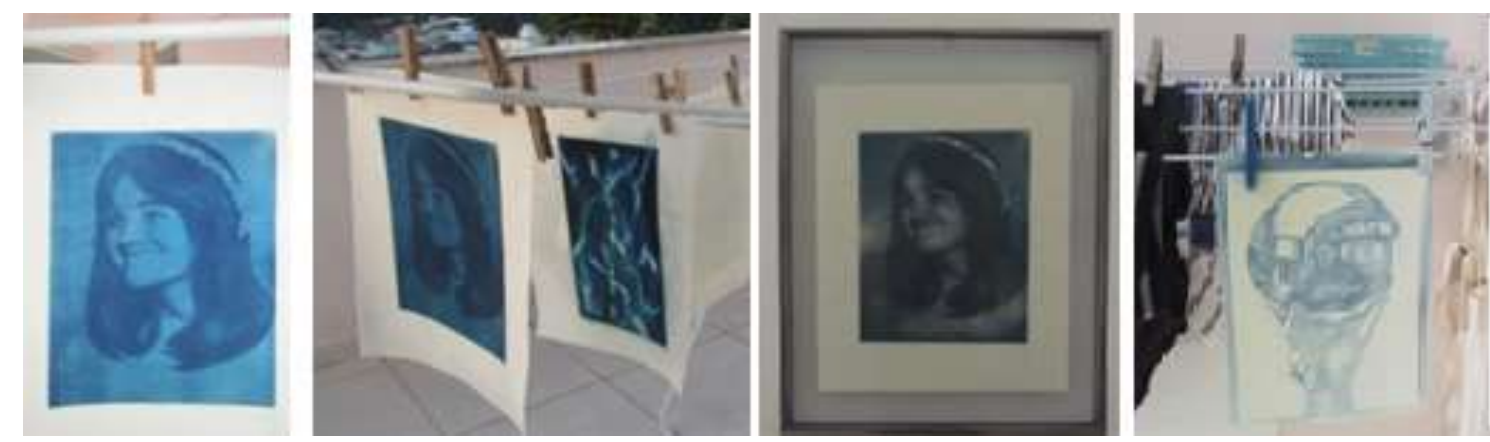

Figura 24 (A, B, C, D) : Imagem do processo de cianotipia e colocação no quadro.

Fotografias e obra do autor, 2014.

Fonte: Acervo do artista

Essas experiências permitiram conhecer as dificuldades encontradas em relação ao tempo de exposição, remoção dos resíduos de cianeto com água corrente, tipo de impressora mais adequado para fazer o negativo da imagem, pincel, prendedores, evitar a formação de vapor d'água entre as placas de vidros, etc.

Somente praticando e vivenciando é que podemos obter experiência e conhecimento.

Para finalizar essas experiências, apresento uma síntese, em três etapas, do processo feito com a técnica de cianotipia. São apresentados quatro trabalhos escolhidos, os respectivos negativos e os resultados alcançados. 


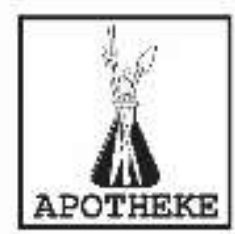

\section{Revista \\ APOTHEKE}

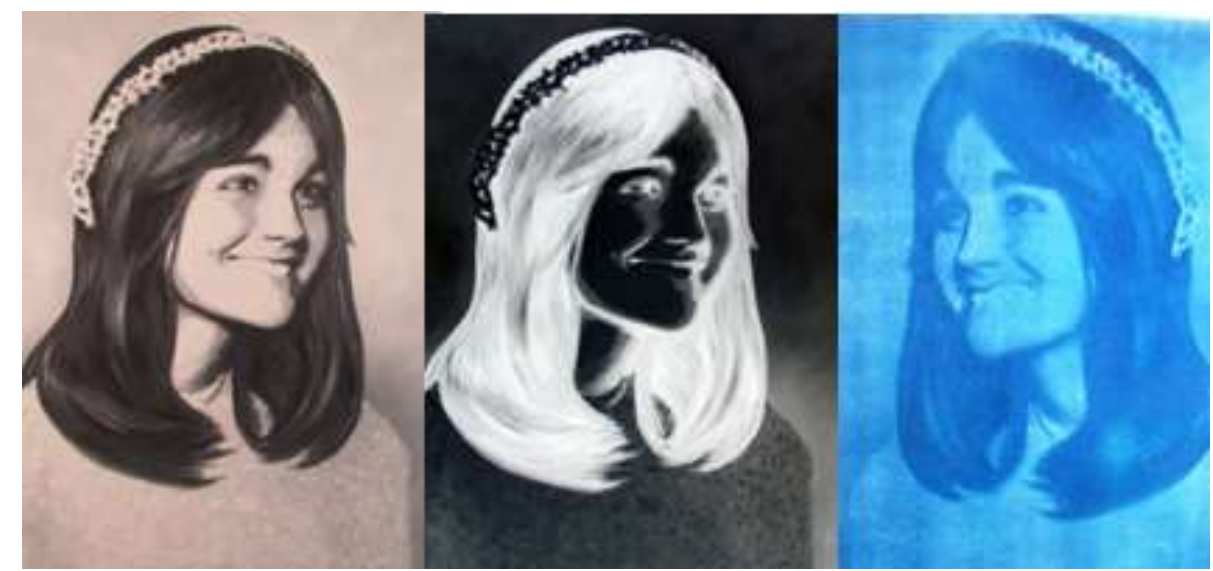

Figura 25 (A, B, C, D) : Retrato feito pelo autor, negativo e resultado alcançado pela técnica.

Fotografias e obra do autor, 2014.

Fonte: Acervo do artista

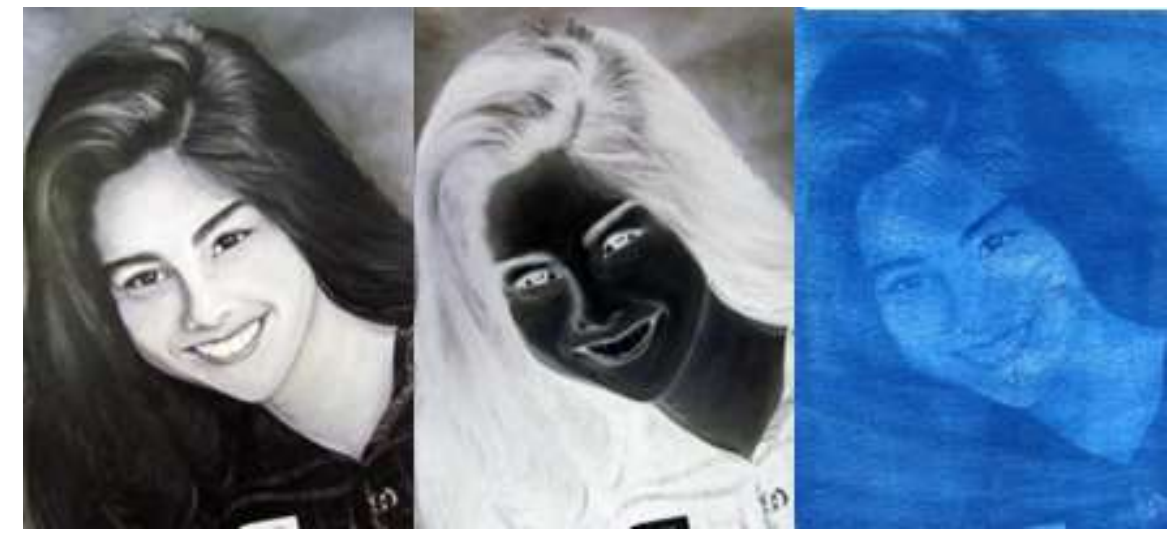

Figura 26 ( A, B, C ) : Retrato feito pelo autor, negativo e resultado alcançado pela técnica. Fotografias e obra do autor, 2014.

Fonte: Acervo do artista
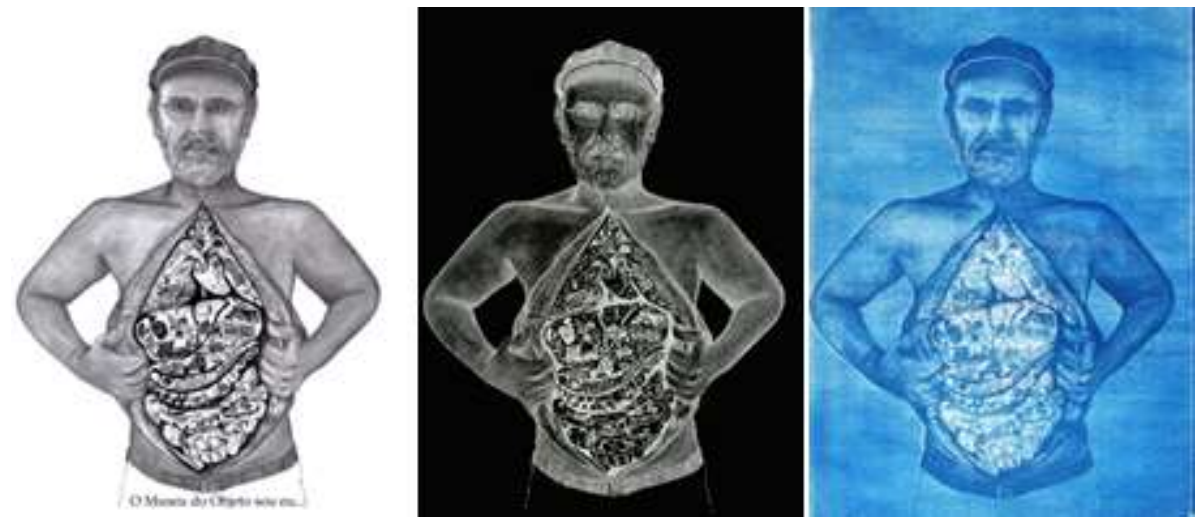

Figura 27 (A, B, C) : Autorretrato feito pelo autor, negativo e resultado alcançado. Fotografia e obra do autor, 2014. Fonte: Acervo do artista 


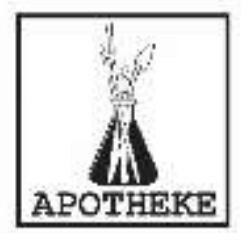

\section{Revista \\ APOTHEKE}
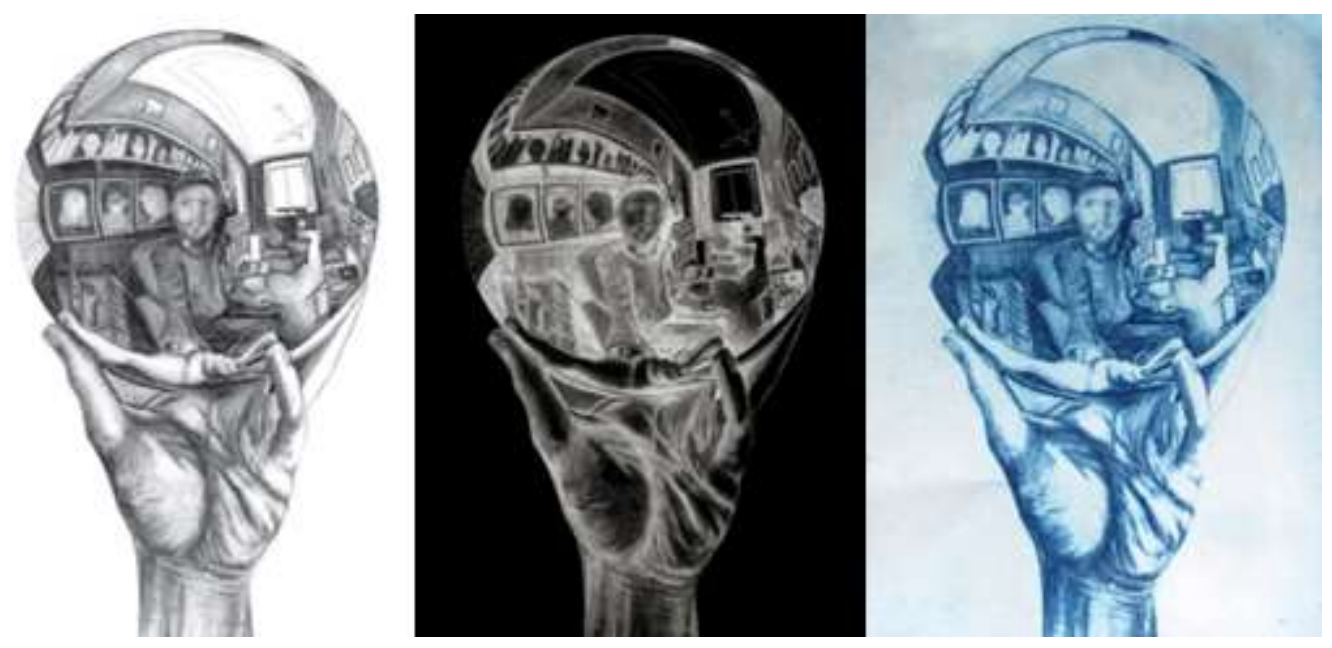

Figura 28 (A, B, C) : Autorretrato feito pelo autor, negativo e resultado alcançado.

Fotografias e obra do autor, 2014.

Fonte: Acervo do artista

A realização dessas experiências com a técnica de monotipia e cianotipia permitiu fazer uma conexão entre a teoria e a prática. Com isso, novos conhecimentos são adquiridos e novas possibilidades são oferecidas no fazer do processo artístico como meio para externar a subjetividade poética pela prática vivenciada. São descobrimentos e novas possibilidades conhecidas, experimentadas e aplicadas na busca de novos conhecimentos a cada impressão.

\section{REFERÊNCIAS}

CIANOTIPIA.

<https://br. search.yahoo. com/yhs/search?hspart=iry\&hsimp=yh s-fullyhosted_003\&type=blfnt_f2\&p=cianotipia>. Acesso em: 25 fev. 2015.

GIOVANNI Benedetto Castiglione. Disponível em: <http://pt.wikipedia.org/wiki/Giovanni_Benedetto_Castigl ione>. Acesso em: 25 fev. 2015.

HERSCHEL, John. Disponível em: <http://pt.wikipedia.org/wiki/John_Herschel consulta>. Acesso em: 25 fev. 2015.

MEYER, Ralph. Manual do Artista. Editora Martins. São Paulo. 2006.

MONOTIPIA. O que é e sua descoberta. Disponível em: <http://wikipédia.org/wiki/Giovanni_Benedetto_Castiglione>.

Acesso em: 25 fev. 2015.

REGO, Jorge. A luz que desenha imagens. Disponível em: <http://jorgerego.blogspot.com.br/2005/05/cianotipia.html>. Acesso em: 25 fev. 2015. 